\title{
Histological, Scanning And Transmission Electron Microscopic Studies On The Possible Protective Role Of Ginger Extract Against Acrylamide Induced Intestinal Damage In Mice
}

\author{
Hala Galal El-Tantawi \\ Department Of Zoology -Faculty Of Science - Ain Shams University
}

\begin{abstract}
Objective: This study was carried out to evaluate the protective effect of ginger Zingeber officinale extract (ZOE) against the acrylamide (AC) which is an industrial chemical used in water treatment and it is synthesized during cooking of starch food at high temperature.

Method: Thirty adult male albino mice, each weighs 20-25 g were divided into three groups (10 mice/group): (I)control group. (II)acrylamide treated group. (III) acrylamide \& ginger group. Acrylamide was given to experimental animals in the drinking water at a nonlethal dose of 200 p.p.m for 10 weeks (3 days/week). Ginger extract was orally administrated at $50 \mathrm{mg} / \mathrm{L}(\sim 5 \mathrm{ml} /$ day) for 10 weeks (3 days/week). The ileum samples were collected for light microscope study and for scanning and transmission electron microscope examination.

Results: This study revealed that acrylamide induces pathological changes of the ileum of the treated mice specially the absorptive epithelial cells. The scanning electron microscopic study revealed damage of the ileal villi, some red blood corpuscles appeared at the site of damage. The transmission electron microscopic examination clearly demonstrated degeneration of most cell organelles as mitochondria, deterioration and degranulation of the rough endoplasmic reticulum, dilatation of Golgi apparatus.

Conclusion: The administration of ginger extract decreased the histological alterations and ensuring the anti-inflammatory, and antitoxic effects of ZOE at its chosen dosage level.
\end{abstract}

Key words: Acrylamide - ginger- ileum.

\section{Introduction}

Acrylamide is an industrial chemical used in the synthesis of polyacrylamide and has multiple applications as additive for sewage and water treatment (Smith and Oehme, 1991). Individuals can be exposed to acrylamide either in their workplace or in the environment (Marsh et al., 1999). Recent findings of the presence of acrylamide in starch foods cooked at high temperature have refocused worldwide attention on its carcinogenicity (Tareke et al., 2002). In addition, acrylamide is used extensively in molecular laboratories for gel chromatography (LoPachin, 2004).

According to WHO (2002), the average intake of $70 \mu \mathrm{g}$ of acrylamide per day for an adult would be associated with a lifetime cancer risk. Studies in animal models and humans are necessary to better understand the toxicity of acrylamide .It was shown that acrylamide might be formed through the Maillard reaction from amino acids (e.g asparagines) and reducing sugars (e.g glucose) (Mottram et al., 2002). Glycidamide, a metabolite of acrylamide, binds to DNA and can cause genetic damage. Prolonged exposure to acrylamide has induced tumours in rats, but cancer in man has not been convincingly shown. The International Agency for Research on Cancer (IARC) has classified acrylamide as "probably carcinogenic to humans" (IARC, 1994). Barber et al. (2001) reported that the rate of acrylamide conversion to its epoxide metabolite glycidamide is higher during subchronic dosing conditions.

On the other hand the ginger has been widely studied for its pharmacological activities and has been reported to exhibit antiinflammatory, antipyretic, antimicro-bial, hypoglycemic, antimigraine, antiox-idant, hepatoprotective, diuretic, hypocho-lesterolemia (Langner et al.,1998; Mascolo et al.,1989) and antihypertensive activities (Ghayur and Gilani., 2005). Phytochemical studies showed the presence of pungent 


\section{Hala Galal El-Tantawi}

principles, such as gingerol, shogoal, zingerone and paradol (Connell and McLachan., 1972).

The rhizome of the plant Zingiber officinale roscoe, commonly known as ginger, has been commonly used as a food additive and spice as well as phytomedicine since ancient times. The typical use of ginger in the kitchens as a condiment began in the $13^{\text {th }}$ century; which enhanced the importance of this rhizome in european markets (Langner et al.,1998). More commonly, ginger has been traditionally used in disorders of the gastrointestinal tract, as a stomach laxative, sialogogue, gastric emptying enhancer, appetizer, antiemetic and antidyspepsic and at the same time as an antidiarrheal and anticolic agent (Ghayur and Gilani., 2005; Nadkarni, 1976).

Several studies conducted in animals (Yamahara et al., 1990; Qian and Liu., 1992) and humans (Mowerey and Clayson., 1982; Sharma and Gupta., 1998) showed the prokinetic action of ginger; however, the precise mechanism of its action is not yet clear. On the contrary, some studies also reported the inability of ginger to impart any stimulant effect on the bowel (Stewart et al., 1991; Phillips et al.,1993); while others showed that ginger exhibits a spasmolytic action but the precise mode of action remains to be elucidated.

However, no study pointed out the presence of a combination of stimulatory and inhibitory activities in ginger, because of scarcity of information on acrylamide and its metabolites on the intestinal tissue. This has opened up new avenues for understanding the pathogenesis of intestinal degeneration induced by acrylamide and the role of ginger in minimizing the toxicity induced by it.

\section{Material And Methods \\ Materials}

1-Acrylamide (AC) is patented by P.S Park scientific limited, Northhampton, United Kingdom. (AC) is a chemical intermediate (monomer) used in synthesis of polyacrylamides.

Acrylamide monomer is a white crystalline form, soluble in water, ethanol, methanol and acetone. Its chemical formula is $\mathrm{CH}_{2} \mathrm{CHCONH}_{2}$. Synonyms of acrylamide are: 2-propenamide, ethylene carboxamide, acrylamide and vinylamide.
The experimental animals were given acrylamide in drinking water at a dose of 200 p.p.m according to Ko et al. (1999).

2-Ginger or Zingeber officinale roscoe (Family Zingeberaceae). Ginger ethanolic extract was prepared from conc-entrated pure ginger powder. The stock solution of the ginger extract at conce-ntration $1 \mathrm{~g} / \mathrm{l}$ was prepared in $22 \%$ alcohol $(200 \mathrm{mg}$ of ginger exract was dissolved in $44 \mathrm{ml}$ of ethanol and the volume was then adjusted to $200 \mathrm{ml}$ with water). Drinking solution was prepared freshly every 3 days, by dilution of $25 \mathrm{ml}$ of the ginger extract stock solution into $500 \mathrm{ml}$ of water, resulting in final concentration of 50 $\mathrm{mg} / \mathrm{l}$ of ginger extract in $1.1 \%$ alcohol according to Bianca et al. (2000).

\section{Experimental design}

This study was carried out on 30 male adult CD-1 mice, each weighs $20-25 \mathrm{~g}$; they were divided into three groups, 10 mice each. The first group served as control and received $1.1 \%$ alcohol $(11 \mathrm{ml}$ of alcohol in 11 water) for 10 weeks and fed ad libitum. The second group was given acrylamide at a dose 200 p.p.m in drinking water for 10 weeks (3 days/week) according to Ko et al. (1999). The third group received ginger (ZOE) at $50 \mathrm{mg} / \mathrm{L}(\sim 5 \mathrm{ml}) 1$ hour prior to the administration of acrylamide (200 p.p.m) in drinking water for 10 weeks (3 days/ week) according to Bianca et al. (2000).

\section{Methods}

Acrylamide was administered in drinking water, and after 10 weeks (3 times /week) the animals were decapitated; small parts of the ileum were immediately excised and fixed in alcoholic Bouin for light microscopic study. Specimens were dehydrated, cleared and embedded in paraffin wax. Sections of $5 \mu \mathrm{m}$ in thickness were stained with hematoxylin and eosin (Chayen et al., 1973). The cytoplasm appeared reddish-pink and the nuclei acquired a blue colour.

Other pieces of the ileum were fixed in $2 \%$ glutaraldehyde in 0.1 phosphate buffer, postfixed in $1 \%$ osmium tetra oxide for 2 hours at $4^{\circ} \mathrm{C}$, dehydrated and embedded in epon. The semithin sections were stained with toluidine blue and the ultrathin 
sections stained with uranyl acetate and lead citrate and examined on transmission electron microscope (JEOL- Ex 1010 transmission electron microscope at $\mathrm{Al}-$ Azhar University).

For scanning electron microscopic examination (SEM), small pieces of ileum were washed several times in distilled water. They were fixed in phosphate buffered $2.5 \%$ glutaraldehyde for 3-4 hr and postfixed in phosphate buffered $1 \%$ osmium tetra oxide for $1 \mathrm{hr}$. The specimens were dehydrated in a graded series of ethanol and dried at a critical point using liquid $\mathrm{CO}_{2}$. The dried specimens were attached to the stubs and then coated with gold by coating apparatus JFC-1100E Ion sputter. These specimens were examined on JEOL 1200EX II electron microscope at 28 $\mathrm{KV}$ at the Faculty of Science, Ain Shams University, Cairo, Egypt.

\section{Results}

\section{General observations}

Mice treated with acrylamide exhibited restlessness and a marked increase of body weight.

\section{Light microscopic examination a- Control animals}

The ileal mucosa of the control mice is built up of numerous folds forming the villi, through which the connective tissue of the lamina propria containing the simple tubular glands i.e; the crypts of Lieberkühn is found (Fig.1).

The lining epithelium of the villi is composed of many cell types, such as the absorptive columnar epithelial cells (enterocytes), goblet cells and Paneth cell. The predominant cell type is the enterocytes; they have striated borders, finely granular cytoplasm and oval basally located nuclei (Figs.2\&3). The goblet cells are scattered between the enterocytes, they have heavily chromatinated basal nuclei (Fig.2).

The epithelial layer lining the crypts of Lieberkühn is continuous with that of the villi (Fig.4). The lamina propria of the mucosa is formed of fine connective tissue containing lymphocytes, fibroblasts and blood capillaries (Fig.5).

\section{b- Acrylamide treated animals}

Mice treated with acrylamide for 10 weeks revealed marked histopathological alterations. The lining epithelium of the mucosa showed marked discontinuity (Figs. 6\&11). The absorptive columnar cells displayed signs of necrosis characterized by distinct vacuolations and pyknotic nuclei (Figs.6\&7).

The mucus-secreting goblet cells were few (Figs. 6, 7\&9). These changes resulted in the formation of large clear spaces in this material. In addition, lymphocytic infilteration was prominent and numerous enlarged lymph nodules appeared in the lamina propria of the villi (Fig.8).

The epithelial cells of the crypts of Lieberkühn were faintly stained with illdefined cell boundaries, vacuolated cytoplasm and pyknotic nuclei (Figs. 9\&10).

\section{c-Animals received ginger together with acrylamide}

The histological structure of the ileal mucosa appeared more or less normal (Figs. 12\&13). The absorptive columnar epithelial cells lining the crypts of liberkühn and the villi were clearly demon-strated and were more or less similar to that of the control group (Figs.14\&15). The lamina propria showed less damage and alterations (Fig.16).

\section{Scanning electron microscopic examination}

The filiform and foliate ileal villi of the control animals appeared normal, with non-damaged cover. Few mucous secretions were noticed, and normal submucosal layer appeared as a base for the villi (Figs. 17\&18).

Administeration of acrylamide (AC) for 10 weeks resulted in apparent changes appeared in some surface areas of the villi (Figs.19\&20). Also, mild bleeding appeared as red blood corpuscles in the intervillar spaces and facing the lumen, this bleeding was accompanied with severe damage of the villi (Fig.21).

On the other hand, animal group which had received the ginger (ZOE) before (AC), showed that the villi appeared more or less normal. Also, some of mucous secretions were observed but no bleeding or blood corpuscles were shown (Figs. 22, 23 \& 24).

\section{Transmission electron microscope} examination

\section{a. Control animals}

Electron microscopic examination of the ileal mucosa revealed that the ileal 


\section{Hala Galal El-Tantawi}

mucosal epithelium is built up of one layer containing many types of cells resting on a basement membrane.

The absorptive columnar cells have ovoid basally located nuclei (Fig.25). Each nucleus had a prominent nucleolus and heterochromatin clumps mostly adjacent to the inner surface of the nuclear envelope. The cells are provided with microvilli at their luminal surfaces. The microvilli appeared as closely packed, long, parallel projections on the apical surfaces of the epithelial cells (Fig. 28).

The cytoplasm of the absorptive cells contained mitochondria of various shapes with well developed cristae (Figs.26\&27). Rough and smooth endoplasmic reticulum (ER) were seen in the cytoplasm (Fig.27).

The endoplasmic reticulum ER is formed of a continuous network of canaliculi and saccules throughout the cell especially near the nucleus (Fig.26).The reticulum was predominantly rough (carrying ribosomes), but smooth ER was also found especially towards the apex (Fig.29).

At the cell periphery, especially near the apex, junctional complexes bound the adjacent cells together (Fig.27). The lateral cell interfaces showed interdigitations of adjacent plasmalemmae.

The Paneth cell (Fig.30) appeared with oval, basal nucleus and prominent nucleolus. Abundant rough endoplasmic reticulum and large secretory granules were clearly shown.

Goblet cells were few among the absorptive cells in the ileum, without brush border. They contained electron-lucent mucus secreting granules and basal nuclei (Figs.31\&32).

\section{b. Acrylamide treated animals}

The ileal epithelial cells of mice recieved acrylamide for 10 weeks, displayed several changes in their ultrastructure. In some cells, especially those in the villus base, the microvilli forming the brush border were partially degenerated and showed few plebs (Fig.33). In other cells, especially those located at and near the villus tip, the microvilli appeared only slightly affected (Fig.35). Severe destructive changes in the absorptive columnar epithelial cells were observed. Most nuclei of the cells of the treated animals showed marked alterations
(Fig.33); some of them displayed few chromatin and others seemed pyknotic and had highly irregular outlines, internal cloudy appearance with the disappearance of a prominent dense nucleolus (Fig.35). Moreover, in some highly injured cells, the nuclei were degenerated (Figs. 35, 36\&37).

The Golgi apparatus of acrylamidetreated animals cells seemed hypertrophied, so its cisternae were dilated (Fig. 34). The arrangement of the rough ER cisternae was somewhat disturbed; in some regions of the cytoplasm these cisternae seemed fragmented (Fig.35). Many cells were severely injured (Fig.37). Figure 36 represents two cells in their way to degenerate. They appeared undergoing cloudy degeneration, and the ER lumen was dilated and degenerated.

Acrylamide administration for 10 weeks revealed that the majority of the mitochondria were slightly swollen, and the cristae of some of them had lost their normal appearance and became difficult to be distinguished (Figs. 34\&35).

The goblet cells became few, tall, more globular and many vacuoles were found within the cytoplasm. Their nuclei showed pyknosis and became more basally located. Smooth endoplasmic reticulum succuli became very dilated (Fig.38).

Figures 39 and 40 showed damage of the lamina propria in the core of the ileal villus. This damage was accompanied with the presence of many lymphocytes.

\section{c. Animals reiceved ginger together with acrylamide}

The electron microscopic examination ileum of mice that received ginger (ZOE) extract 1 hour before the acrylamide administration showed that the general architecture of the ileal tissue was more or less similar to that of the control group. The nuclei of the absorptive cells appeared with normal basal position surrounded by abundant cytoplasm, the microvilli of the brush border were projecting in a regular and normal manner (Fig.41). Some cisternae of Golgi apparatus, and many lysosomes were prominent (Fig.42). In addition, a plenty of mitochondria and the rough endoplasmic reticulum were observed (Fig.44). Different types of leukocytes with normal nuclei and cytoplasm were clearly noticed (Fig.43). 


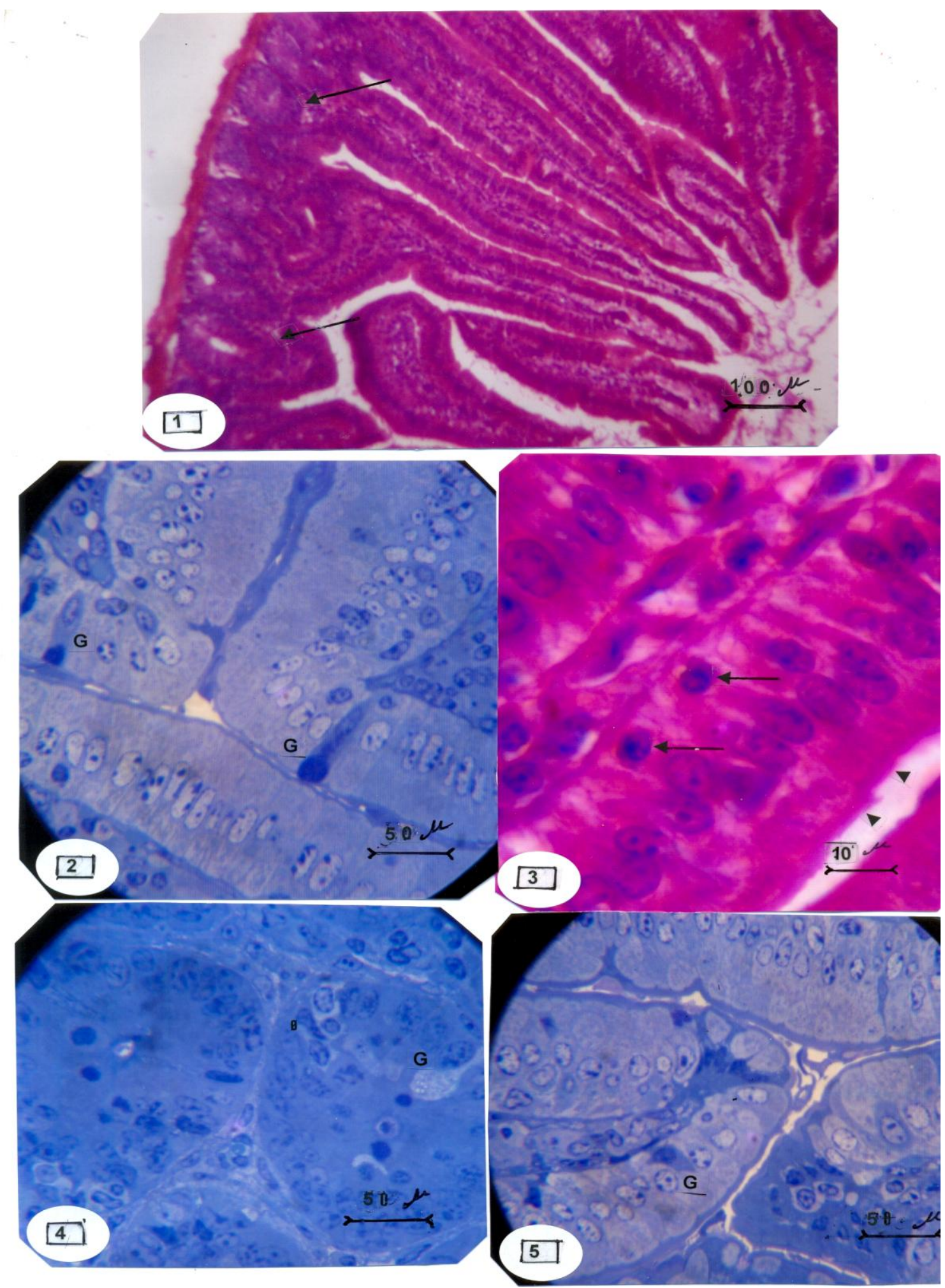

Figures 1-5: Photomicrographs of transverse sections of the ileum of control mice.

Fig.1: Photomicrograph of transverse section of ileum of control mice showing the mucosal villi, and the crypts of Lieberkuhn (arrows). (H\&E)

Figures 2,3 \&5: A magnified regions, illustrating the structure of ileal villi showing the simple columnar epithelial cells with the brush border (arrow head) interspersed with few goblet cells (G) and interepithelial lymphocytes (arrows).

(Figs. $2 \& 5 \mathrm{H} \& \mathrm{E})$ (Fig.3.TB)

Fig. 4: Showing the structure of the crypts of Lieberkuhn lined with columnar epithelial cells and few goblet cells. 


\section{Hala Galal El-Tantawi}

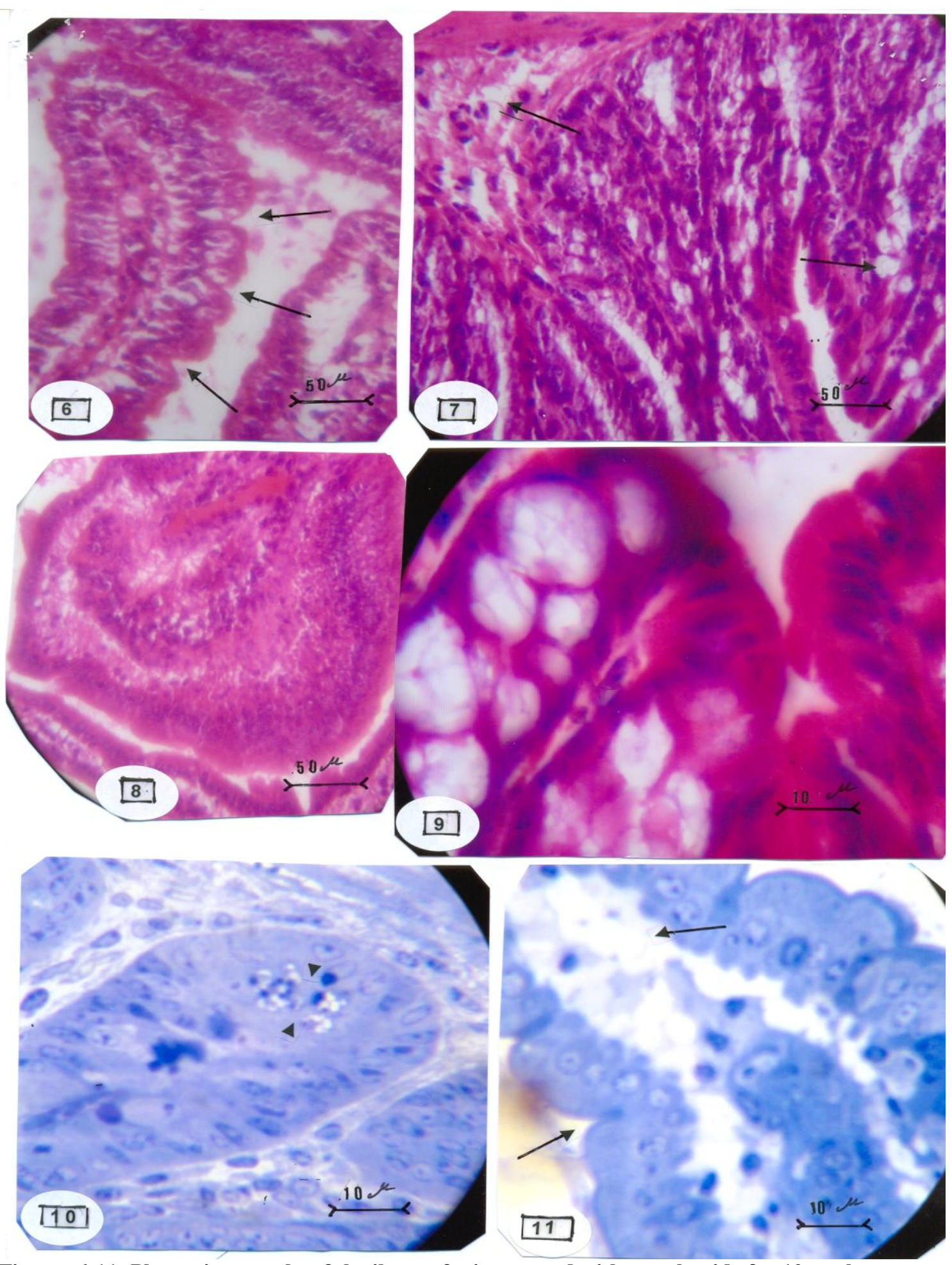

Figures 6-11: Photomicrographs of the ileum of mice treated with acrylamide for 10 weeks.

Figures 6,7 \&11: Showing vacuolation and degeneration of lamina propria, apparent hyperplasia of the surface columnar cells which appeared to be separated from each other at many sites(thin arrow).

(Figs .6\&7H\&E, Fig.11 TB)

Fig.8: A magnified part of the mucosal villus of ileum of mice revealed the loss of villus architecture and increase of interepithelial lymphocytes with few goblet cells.

(H\&E)

Fig.9: A magnified part of the villus apical region, the cytoplasm showing vacuolation. (H\&E)

Fig.10:Illustrating the crypts of Lieberkühn, faintly stained epithelial cells, Pyknotic nuclei and vacuolation of the cytoplasm (arrow heads).

(TB)

Fig. 11: Showing damage and vacuolation of lamina propria (right upper arrow), also notice discontinuity of surface columnar cells (left lower arrow). 


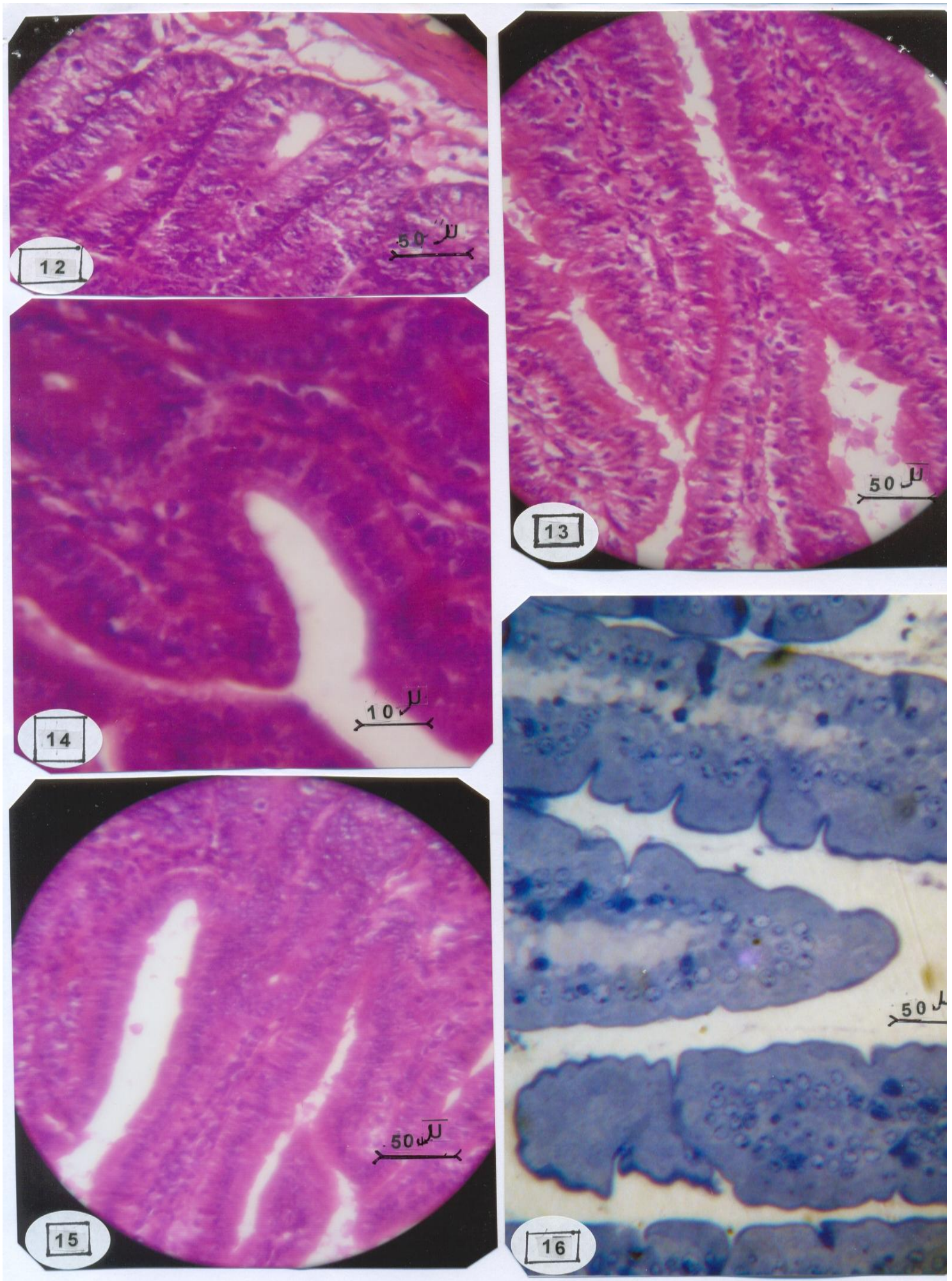

Figures 12-16: Photomicrographs of the ileum of mice treated with acrylamide after receiving the ginger extract ZOE.

Figures12\&13: Showing normal histological structure of the columnar epithelial cells of the ileal villi and lining of the crypts. ( $H \& X)$

Figures 14\&15: Showing a magnified part of the inner regions of the crypts and columnar cells which facing the lumen, the villi regained their normal structure, lamina propria appeared with more or less normal structure in the core of the villi.

$(\mathrm{H} \& \mathrm{E})$

Fig.16: Showing the mucosal villi with more or less normal lamina propria. Notice that the villi become more thinner than of control villi, and very few goblet cells $(\mathrm{G})$ are observed. 


\section{Hala Galal El-Tantawi}
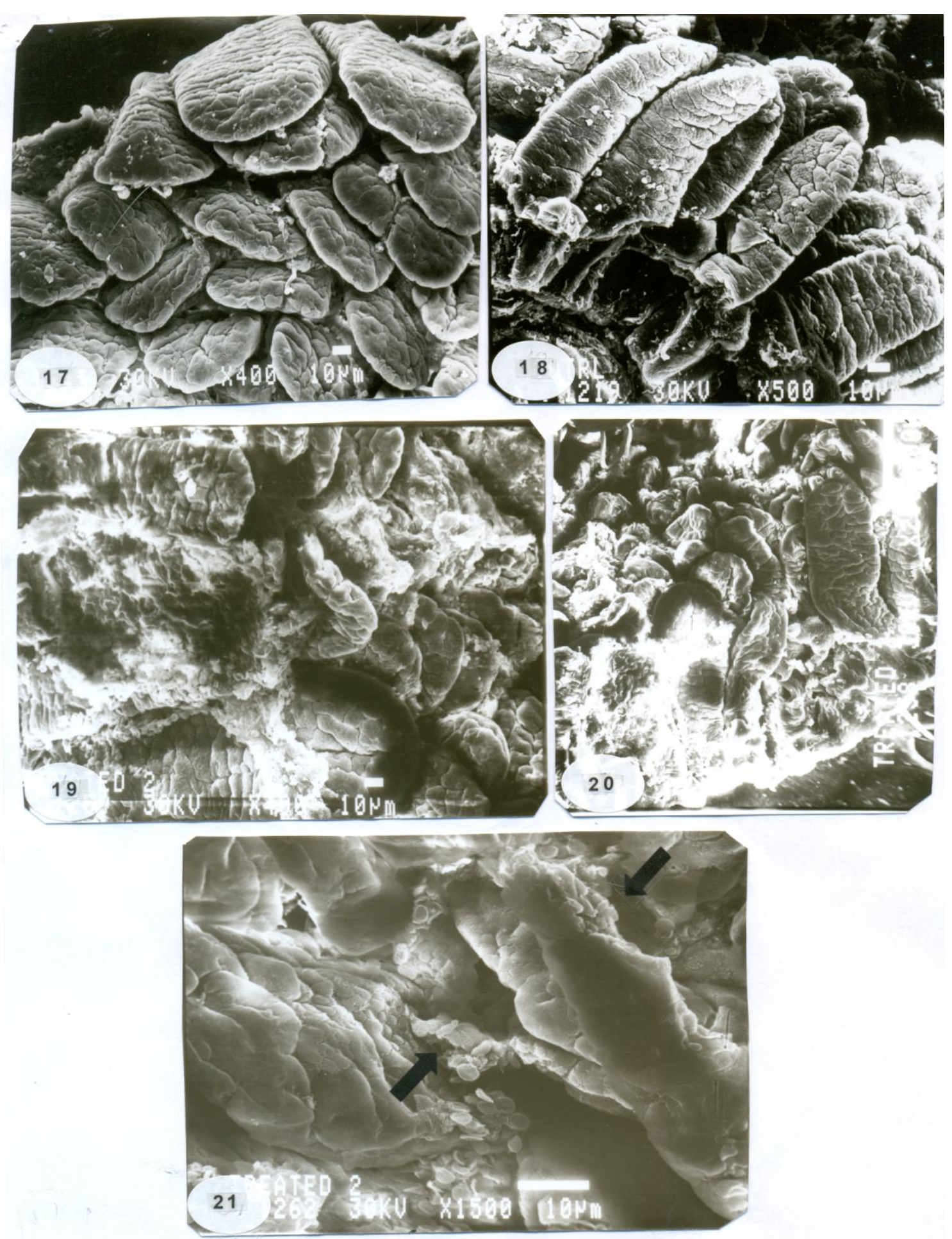

Figures 17\&18: Scanning electron micrographs of the dorsal surfaces of different types of mucosal villi (filiform \& foliate) of ileum of control mice.

Figures 19-21: Scanning electron micrographs of the ileal villi of mice treated with the acrylamide, showing loss of the normal structure of the villi accompanied with damage and bleeding which is shown in Fig.21 at the sites of red blood corpusles. 
Histological, Scanning And Transmission Electron..............
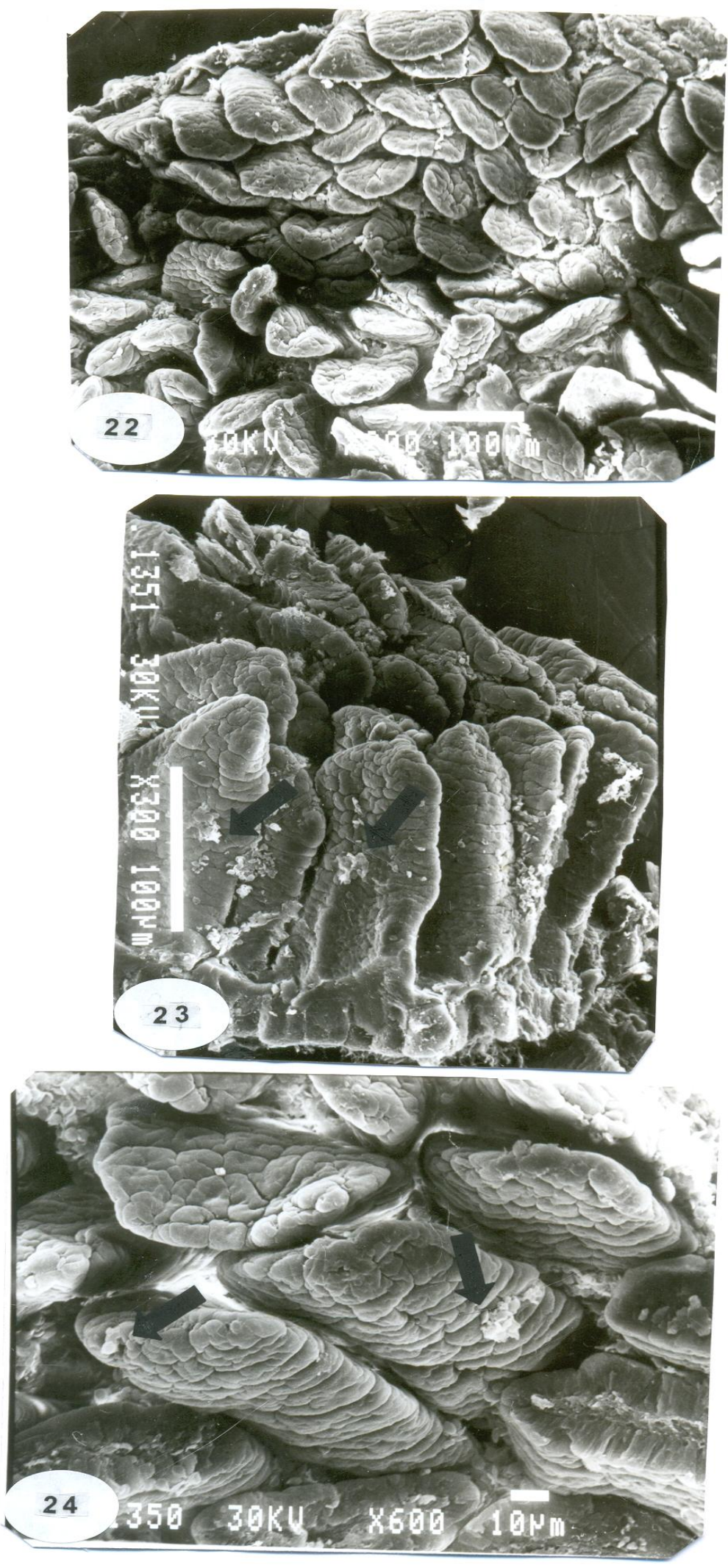

Figures 22-24: Scanning electron micrographs of the ileal villi of treated mice with acrylamide and previously received ginger, showing the normal structure of the villi with presence of mucous secretions (arrows) on the surface. 


\section{Hala Galal El-Tantawi}
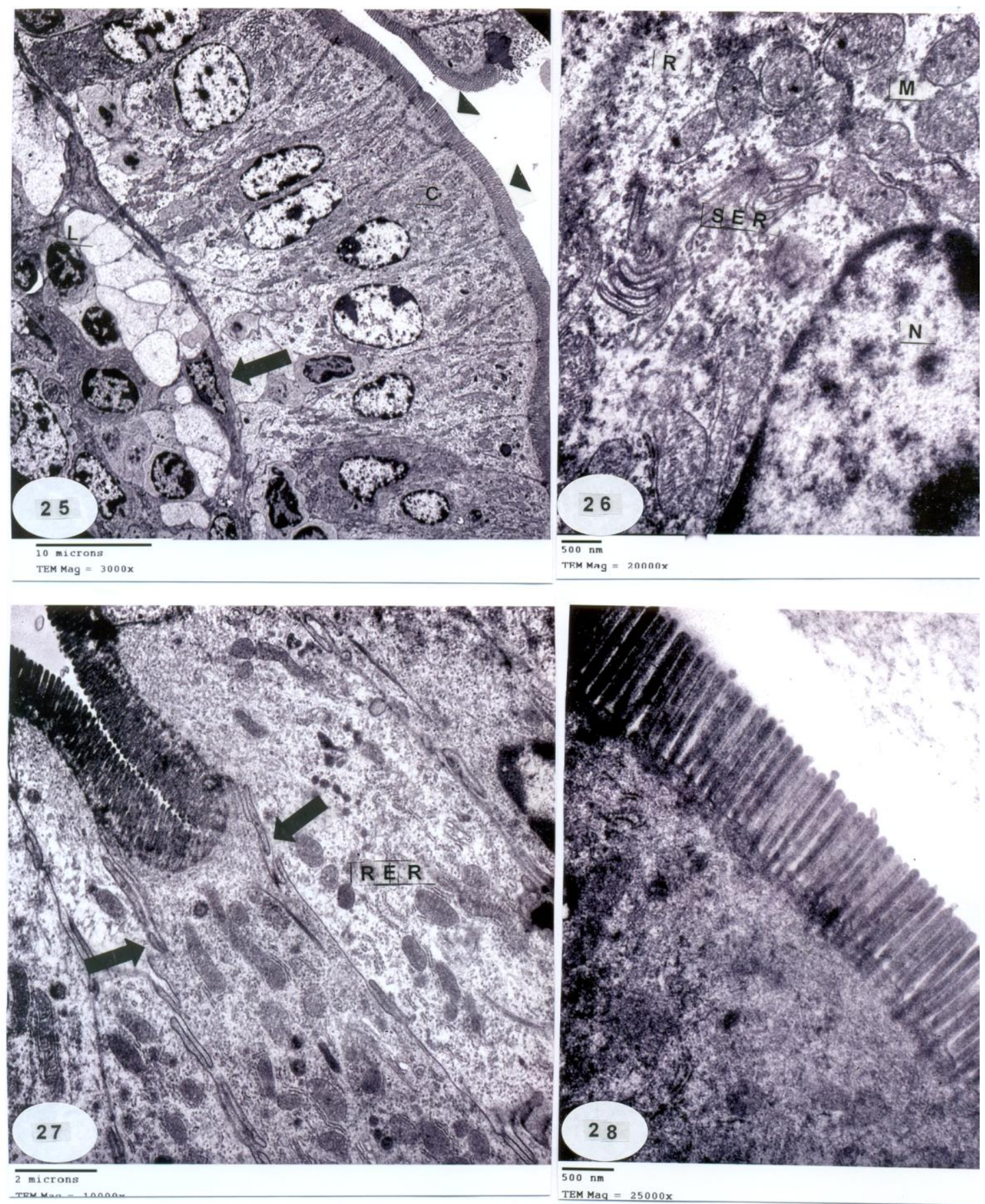

Figures 25-32: Transmission electron micrographs of the ileum of control mice.

Fig.25: Showing the columnar (absorptive) cells (c) with microvilli (arrow heads), different types of cells such as endothelial cells (arrow), and lymphocytes (L) can be shown.

( X 3000)

Fig.26: Showing a magnified part of absorptive cell illustrating the nucleus $(\mathrm{N})$, different forms of mitochondria (M) with well developed cristae. Note the smooth endoplasmic reticulum (SER) and the free ribosomes $(\mathrm{R})$.

( X 20000)

Fig.27: Showing the cellular junctions between the adjacent cells (arrows). Notice the rough endoplasmic reticulum (RER).

(X10000)

Fig.28: Showing the microvilli of control ileum.

(X25000) 

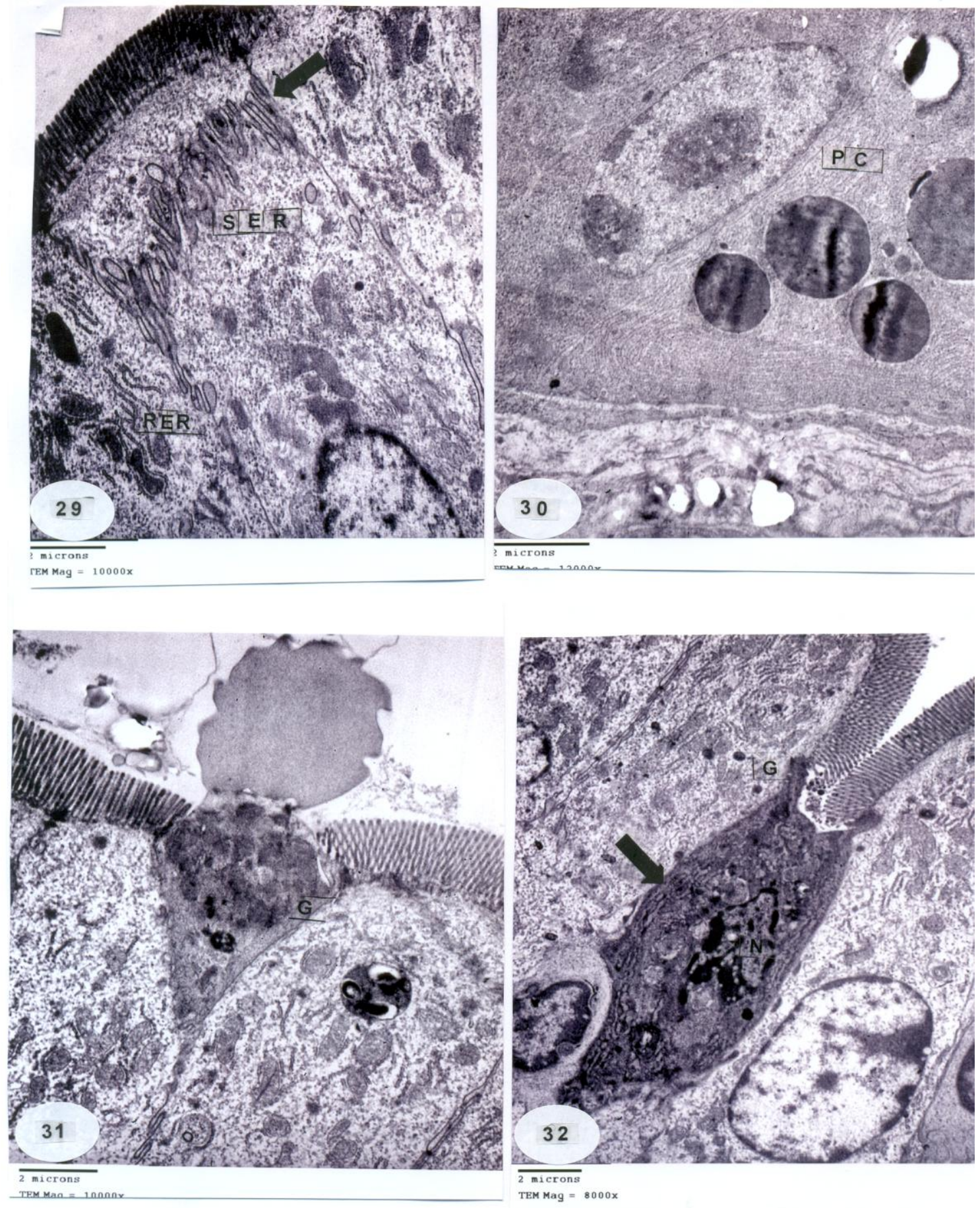

Fig.29: Showing intercellular junctions. Notice infoldings of the plasma membrane and the microvilli (arrows). The rough endoplasmic reticulum (arrow heads) surrounding the mitochondria. SER at the apical regions is observed. $\mathrm{X} 10000$

Fig.30: Showing the normal paneth cell (PC) with basal nucleus, prominent nucleolus, abundant RER and large secretory granules.

X13000

Fig.31: Showing a part of goblet cell $(\mathrm{G})$ with its mucous secretion. $\quad X 10000$

Fig.32: Showing the goblet cell $(G)$ with oval nucleus (n) and many cisternae of RER (arrows) were observed in the dark cytoplasm. 


\section{Hala Galal El-Tantawi}
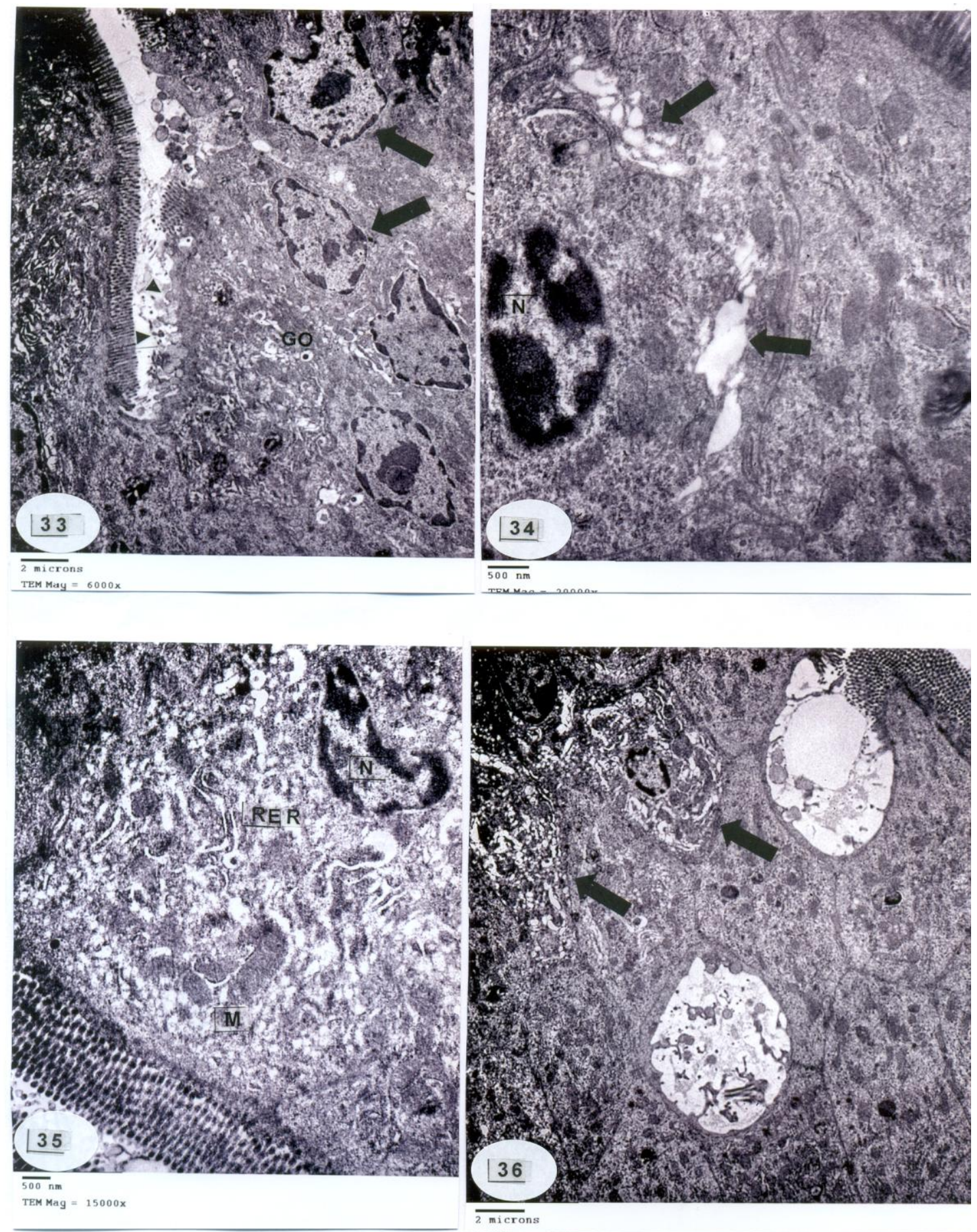

Figures 33-40: Electron micrographs of ileum of mice treated with acry-lamide for 10 weeks at dose 200 p.p.m.

Fig.33: Showing highly damaged columnar absorptive cells, degeneration of the microvilli and formation of blebs (arrow heads), pyknotic irregular nuclei (arrow). Note the hypertrophy of Golgi elements (GO).

X6000

Fig.34: Showing a magnified part of an absorptive columnar epithelial cell with dilated cisternae of Golgi apparatus (arrows).Notice the pyknotic nucleus (N). X20000

Fig.35: Showing highly damaged and degenerated epithelial cells. Notice the pyknotic nucleus $(\mathrm{N})$, fragmentation of RER, complete deterioration of the ground cytoplasm and mitochondria (M). $\mathrm{X} 15000$

Fig.36: Showing complete degeneration and dissolution of the cytoplasm resulting in formation of large vacuoles. Notice the karyolytic cells (arrows). 

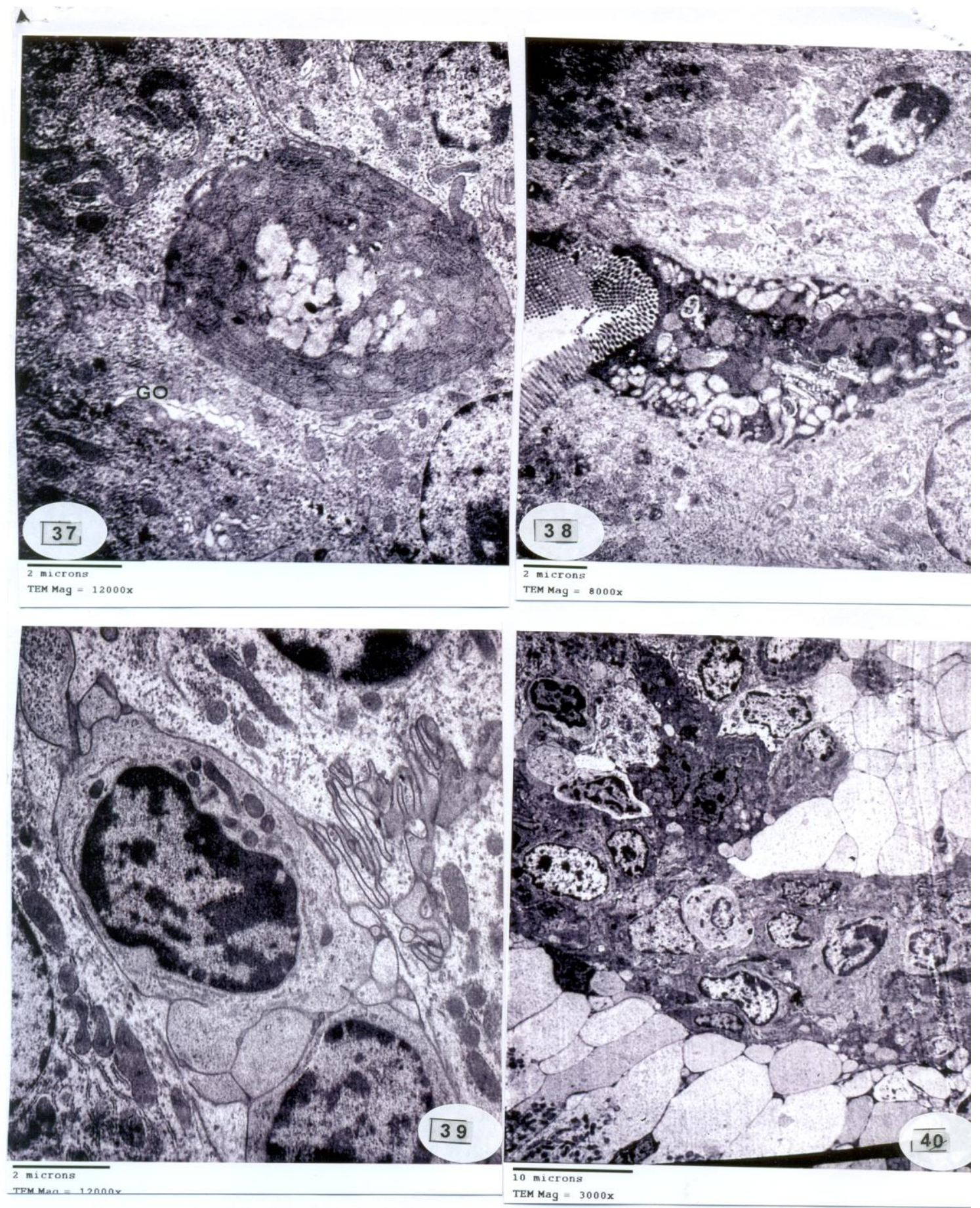

Fig.37: Showing a necrotic cell with complete degeneration of its nucleus. Notice the dilatation of Golgi apparatus cisternae (GO). X12000

Fig.38: Showing atrophy and degeneration of the goblet cell Notice the SER with dilatation of their succuli and disappearance of most cell organelles.

Fig.39: Showing invasion of many lymphocytes. X8000

Fig.40: Showing the core of an ileal villus with many lymphocytes, notice edematous lamina propria. X3000 


\section{Hala Galal El-Tantawi}
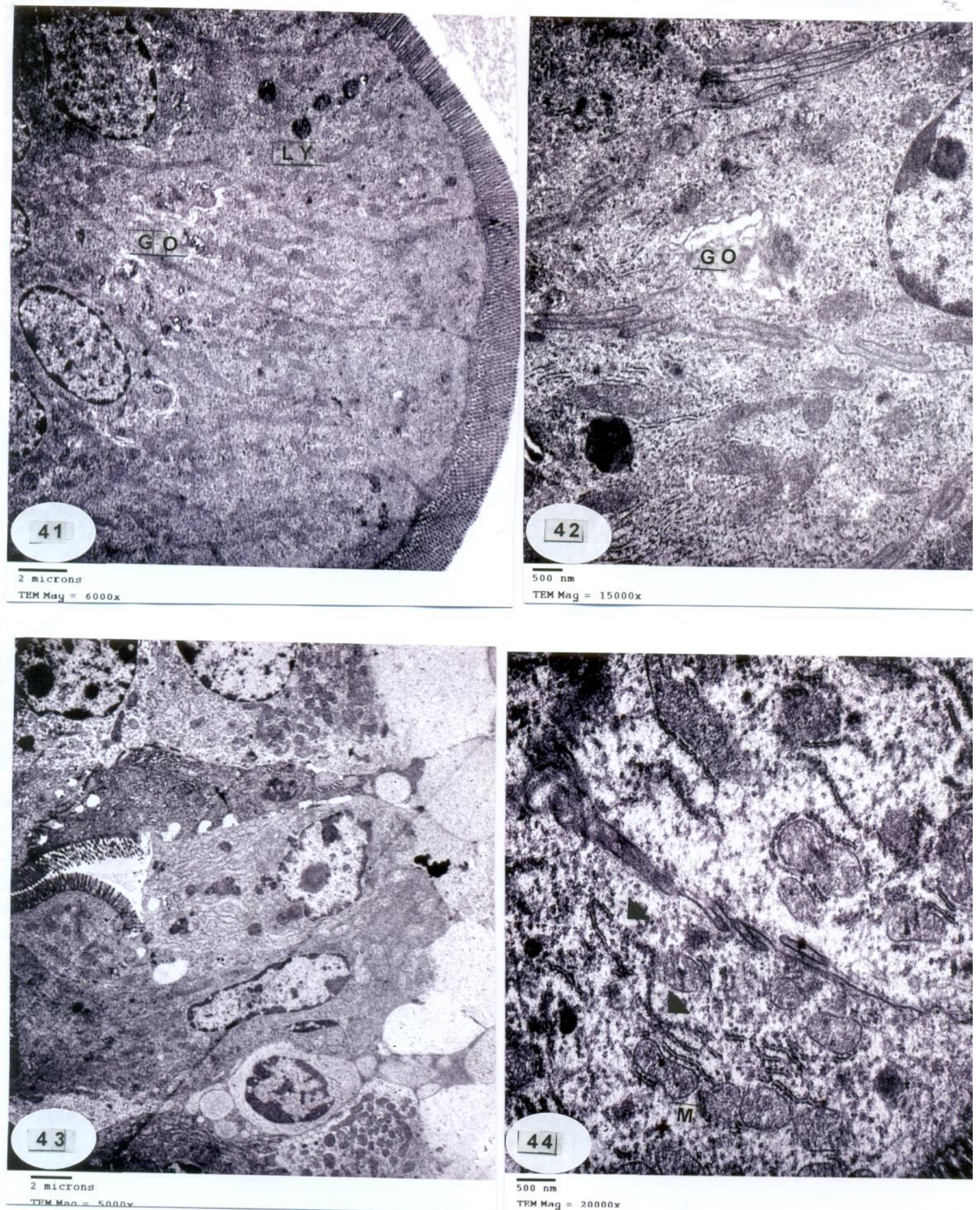

Figures 41-45: Electron micrographs of the ileum of a mouse treated with acrylamide and received the ginger (ZOE) $1 \mathrm{hr}$ prior the acrylamide administration.

Fig.41: Showing the absorptive columnar epithelial cells appeared more or less normal. Lysosomes (LY) were also noticed and mild dilatation of Golgi apparatus cisternae. (GO). X15000

Fig.42: Showing a magnified part of the absorptive columnar cell with dilated cisternae of Golgi apparatus. The cytoplasm contains more or less normal cell organelles.

X 15000

Fig.43: Showing different types of leukocytes and the lamina propria displaying less damage and edema. X5000

Fig.44: Showing normal distribution of the mitochondria (M) normal appearance of RER which carries many ribosome (arrow heads). X20000 


\section{Discussion}

It is evident from the present study that the light, scanning and transmission electron microscopic studies of ileal epithelial cells of the mice adversely responded to the administration of the monomer crystalline substance acrylamide.

Acrylamide is a water soluble organic substance; it is absorbed by all routes and easily distributed throughout the body organs (Barber et al., 2001). In the present study, the mice were chosen for these experiments due to their sensitivity to the toxic substances.

Paulsson et al. (2002) reported neurotoxic and carcinogenic effect of acrylamide in animals, and revealed the lower sensitivity of the rat than that of the mouse to the carcinogenic action of this substance. In 1995 Friedman and his associates concluded that the administration of acrylamide in drinking water increased the incidence of mammary tumours

The gastrointestinal tract is lined with a single layer of epithelium, which forms a highly selection barrier designed to allow the efficient transport of nutrients and water, while preventing the entery of potentially toxic luminal pathogenic organisms and their products or any toxic substances (Adam et al.,2006). According to those authors, (as an interpretation of our finding), acrylamide may have the ability to destroy this intestinal barrier.

At the beginning of the present study after two to three weeks of administration of acrylamide (200 p.p.m) in the drinking water, a marked increase of weight was observed (Marsh et al., 2007). Histopathologically the lymphocytes infilteration were noted, this finding come in agree with the physiological explanation which based on the pharmacokinetic model for acrylamide and it was found that it is distributed within five compartments (arterial blood, venous blood, liver, lung and all other tissues lumped together) (Kirman et al., 2003). The present results showed that the superficial luminal cells of the ileal villi of the treated animals were affected; this agree with studies on aspirin which have shown to induce similar damage (Ivey et al., 1980). Vacuolar degeneration, nuclear pyknosis, cloudy swelling and necrosis were of the most marked signs of tissue impairment in the present study. These destructive changes were similarly reported in the colon, nervous and reproductive systems and produce tumurs in certain hormonally responsive tissues following treatment with acrylamide (Barber et al., 2001).

In the present study, the surface mucosa of the ileum was studied by using scanning electron microscope. After treatment with acrylamide, the cell surfaces were damaged in some areas. Similar results were observed by Specian and Neutra (1980) who investigated the epithelial topography of the surface crypt cell in rabbit and monkey colon. In addition, Bonvicini et al. (1985) reported a clinical investigation of different gastrointestinal diseases by using (SEM); they found that the mucosal surface of the involved mucosa showed certain lesions as bleeding and enlargement of the crypts. These results agree with the present findings where the bleeding appeared and was indicated by the presence of the red blood corpuscles.

Kamel et al. (1985) investigated the structural changes in mouse intestinal villi following lower body heating by using SEM. Some villi were severely damaged at their tips; these are similar to the damage described in the present study after acrylamide treatment.

The ultrastructural study showed that the microvilli of the absorptive columnar cells exhibited signs of degeneration. A similar observation has been described in the small intestine of Tilapia nilotica (Sakr , 1993), where signs of damage and necrosis of the columnar epithelial cells appeared, and then the cells revealed morphological alterations. These results suggested that the columnar cells with their brush borders are the main target cells and act as endocrine disruptors after treatment with chemicals that manifacture plastic products (Besaratinia and Pfeifer , 2004) who concluded that the mutagenicity of acrylamide in human and mouse cells is based on the capacity of its epoxide 


\section{Hala Galal El-Tantawi}

metabolite glycidamide to form DNA adducts. The mitochondrial destruction in the absorptive columnar cells of the ileum of the mice was one of the important results which has been illustrated under various pathological conditions (Adams et al., 1977; EL-Beih et al., 1993).

The present results also showed that the rough endoplasmic reticulum was broken-down, degranulated and fragmented into small structures after treatment with Acrylamide. Such damage is considered to be one of the essential factors responsible for the lowered activity of the cell (Elewa $e t$ al., 1999).

The Golgi apparatus of the cells of treated animals displayed damage. These results confirm the findings of other research workers in different pathological instances (Moussa et al., 1987; Winton and Flaks, 1988; EL-Beih et al., 1994). The observed increase of lysosomes in the cells of animals received ginger together with acrylamide was confirmed by the reports presented by Helman et al. (1985) which revealed that the lysosomes undergo proliferation, abundance and finally rupture at later stages of adverse conditions, with the consequent release of their digestive hydrolases into the cytosol could speculatively account for a considerable proportion of damage produced in the cells as observed in the present work. Moreover, the present study showed that the mucous goblet cells were very few, became elongated but with degenerated nucleus and cytoplasmic organelles; also the Paneth cells were hardly detected. Furthermore, many lymphocytes were seen in the lamina propria. These results explained the potent immunologic function of the ileum, and agree with the study that was carried out by Mohamed et al. (2006).

In the present study, the administration of ginger (ZOE) $1 \mathrm{hr}$ prior to acrylamide in drinking water decreased the histopathological alterations which induced by acrylamide. Where, the ethanolic ginger extract was selected to apply in this study according to Mascolo et al. (1989) who found that the ethanolic ginger extract (100$300 \mathrm{mg} / \mathrm{kg}$ ) contains compounds which inhibit prostaglandin release by leukocytes, which may be responsible for ginger's antipyretic activity and anti-inflammatory effects.
Abdel-Ghaffar (2006) reported that the animals treated with ZOE alone did not show any alteration in serum glucose. So, this could ensure the protective role of ginger against the oxidative hyperglycemia. As far as we can throw more light on the beneficial effect of ginger which is often touted for health benefits and how it was able to reduce the ultrastructural changes caused by acrylamide in the ileal mucosa of mice. Cotran et al. (1994) reported that the mitochondrial dysfunction resulting from acrylamide treatment that would create lack of ATP needed for normal function due to its toxic effect \{histotoxic hypoxia\} and the mitochondria were significantly protected after incorporating ginger.

In consistency with the result of the present study Ghayur and Gilani (2006) found that the extract of ginger exhibits species spasmogenicity in gut tissues, along with a dormant no effect, mediated via the blockade of voltage-dependent $\mathrm{Ca}^{2+}$ channels. Thereby, it maintains the integrity of the plasma membrane and protects it against apoptosis.

Zhongguo (1992) reported that ginger juice exhibits anticholinergic and antihistaminic action. Ginger juice produces antimotion sickness action by central and peripheral anticholinergic and antihistaminic effects. Since it was found that the acrylamide substance is classified as carcinogenic and mutagenic substance that can induce DNA damage in the cell (Barber et al., 2001).

Nakamura and Yamamoto. (1982\& 1983) reported that ginger juice contains antimutagenic components that suppress $\{6\}$-gigerol which is a potent mutagen. So, it could induce DNA repair in damaged cells and induce their apoptosis. In addition, they revealed that the ginger has been repeatedly proven effective in the gastrointestinal distress and is indicated as safe to use in moderate amounts. Overall, studies have proved it to have some effect on motion sickness and post-operative nausea. However, the studies failed to indicate any CNS involvement.

Shulick. 1996; Williams. 1994 and Mclntyre. (1995) concluded that ginger acts as adaptogenic balance, antioxidant, antitoxic probiotic support, systemic stimulant and cytoprotection . 
In conclusion, the histopathological changes of ileum may contribute to toxic effect of acrylamide, DNA changes which lead to pyknosis of the nuclei and necrosis of the cells. Hence, the application of electron microscopy in the present study has the merit of bringing into vision numerous details on the ginger protective role which could be considered a good remedy in gastrointestinal problems that counteracts the histopathological impairments caused by acrylamide and provides improvement of the general health.

\section{References}

1. Abdel-Ghaffar, O. (2006): Protective role of Zingiber officinale extract against arsenic-induced toxicity in female albino Rat. Egypt. J. Zool., 47: 183-201.

2. Adam J, Prashant $\mathbf{K}$, Kathleen A, RyanG,Wooten and AthonyT (2006): Prostaglandin mediated inhibition of $\mathrm{Na}^{+} / \mathrm{H}^{+}$exchanger isoform 2 stimulates recovery of barrier function in ischemiainjured intestine.Am.J.Physiol. Gastrointest. Liver, Physiology, 291:885-894.

3. Adams HR, Isacson EL and Masters BS (1977): Inhibition of hepatic microsomal enzymes by chloramphinecol. J. Pharmacol. Exp.Ther., 203: 388-395.

4. Barber D S, Hunt J R, Ehrlisch M F, Lehning $E$ J and LoPachin R M (2001): Metabolism, toxokinetics and hemoglobin adduct formation in rats following subacute and subchronic acrylamide dosing. Neurotoxicology, 22: 341-353.

5. Besaratinia $A$ and Pfeifer $G$ (2004): Genotoxicity of acrylamide and Glycidamide. J.Nati.Cancer.Inst., 96 (13): 1023-9.

6. Bianca F, Mira R, Tony H, Raymond C and Michael A (2000): Ginger extract consumption reduces plasma cholesterol, inhibits LDL oxidation and attenuates development of atherosclerotic, apolipoprotein E-Deficient mice. Amirican Society for Nutritional Science. 1124-1130.

7. Bonvincini F, Zoli G, Maltarello M C, Bianchi D, Gasbarrini $G$ and Iashi $R$ (1985): Clinical applications of scanning electron microscopy in gastrointestinal diseases. Scanning Electron Microscopy, III: 1279-1294.

8. Borrelli F, Capasso R, Pinto A, Izzo A A (2004): Inhibitory effect of ginger Zingiber officinale on rat ileal motility. Life Science, 74 (23): 2889-96.

9. Chayen J, Bitensky $L$ and Butcher $R$ (1973): Practical histochemistry.Jhon Wiley and sons.London.
10. Connel,DW.; McLachlan, R.(1972): Natural pungent compounds : examination of gingerols, shogaols, paradols and related compounds by thin layer and gas chromatography.J. Chromatogr., 67:29-35.

11. Cotran R S, Kumar V and RobbinsS L (1994):Cellular injury and cellular death .In. Robbins pathologic basis diseases. $5^{\text {th }}$ edition. Saunders W.B.Company, Philadelphia, London.

12. EL-Beih Z M, Amer M A and Ateia M A (1994): Changes in the Golgi apparatus of mammalian cells under the effect of amphetamine and ethanol.Proc. Egypt. Acad.Sci.,44: 109-118.

13. EL-Beih $\mathbf{Z} \mathbf{M}$, Amer $M A$ and Elewa $\mathbf{F} \mathbf{H}$ (1993): Histochemical alterati-ons in succinic dehydrogenase activity in the cells of mice administered erythromycin .Proc.Egypt. Acad.Sci., 43:113-121.

14. Elewa F, Gabry $M$ and Ibrahim $M$ (1999): Ultrastructural changes produced by Diclofenac sodium (voltaren) in the liver and duodenal epithelial cells of guinea pig. Egypt.J.Zool., 33: 133-165.

15. Friedman $M A$, Dulak $L \mathbf{H}$ and Stedham M A (1995): A life time oncogenicity study in rats with acrylamide. Fundam.Appl. Toxicol., 27(1):95-105.

16. Ghayur MN and Gilani AH (2006): Species differences in the Prokinetic effects of ginger. Int. J. Food.Sci.Nutr.,57(1-2):6573.

17. Ghayur $M$ N and Gilani A H (2005): Ginger lowers blood pressure through blockade of voltage-dependent calcium channels.J. Cardiovascular Pharmacol.,45: 74-80.

18. Helman R G, Adams L G, Deeric K R and Bridges $C H$ (1985): The role of lysosomes in the pathogenesis of copperinduced hepatoxicity.Morphological studies .J.Comp.Pathol.,95: 25-35.

19. International Agency for Research on Cancer (IARC) (1994): Monogrph on the evaluation of carcinogenic risks to human: some industrial chemicals N0. 60. IARC, Lyon, France.

20. Ivey KJ, Paone DB and rause WJ (1980): Acute effect of systemic aspirin on gastric mucosa in man.Dig.Dis.Sci.,25:9799.

21. Kamel H, Carr K, Kume S and Marigold J (1985): Structural changes in mouse small intestinal villi following lower body hyperthermia.Scanning Electron Microscopy., II: 849-858.

22. Kirman C R, Gargas M L, Deskin R, Tonner N L and Andersen ME (2003): A physiologically bassed pharmacokinetic model for acrylamide and its metabolite glycidamide, in the rat.J.Toxicol. Environ. Health, A., 66 (3): 253-274. 
23. Ko M H, Chen W P, Lin-shiau S Y and Hsieh S T (1999): Age- -dependent acrylamide neurotoxicity in mice:morphology, Physiology and function. Exp.Neurol., 158 (1): $37-46$

24. Langner E, Greifenberg $\mathbf{S}$ and Gruenwald J (1998): Ginger:history and use. Advances in Therapy.,15(1): 25-44.

25. LoPachin $\mathbf{R}$ M (2004): The changing view of acrylamide neurotoxicity. Neurotoxicology, 4: 617-630.

26. Marsh G M, Lucas L G, Youk AO and Schall LC (1999): Mortality patterns among workers exposed to acrylamide:1994 follow up:Occup. Environ. Med., 56:181-190.

27. Marsh G M, Youk AO, Buchanich J M, Kant IJ and Swaaen G (2007): Mortality patterns among workers exposed to acrylamide: updated follow up.JOEM., 49(1):82-95.

28. Mascolo N, Jain R, Jain $\mathbf{S}$ and Capasso $\mathbf{F}$ (1989): Ethanopharmac-ologic investigation of ginger (Zingiber officinale) .J. Ethano-pharmacol., 27: 129-140.

29. Mclntyre A (1995): The complete woman's Herbal.New York :Henry Holt and C.

30. Mohamed S, Hindawy M, Sakara $Z$ and Soliman M (2006):Light and electron microscopic study of the rabbit ileum at the region of Peyer"s patches.Egyption society of histology and Cytology. The $30^{\text {th }}$ conference. (in print).

31. Mottram DS, Wedzicha BL and Dodson A T (2002): Acrylamide is formed in the Maillard reaction.Nature.,419:448-449.

32. Moussa T A, EL-Beih $\mathbf{Z} \mathbf{M}$ and Amer $M$ A (1987): The Golgi apparat-us of the gastric mucosal cells in normal and organophosph-ate-treated guinea pigs. Egypt. J.Histolo.,10 (1): 115-120.

33. Mowerey D B and Clayson D E (1982): Motion sickness, ginger and psychophysics. Lancet, 1: 655-657.

34. Nadkarni K M (1976): Zingiber officinalle . In India Materia Medica Bombay, Popular Prakashon, pp: 1308-1315.

35. Nakamura $H$ and Yamamato $T$ (1982): Mutagen and anti-mutagen in Ginger, zingiber pfficinalle.Mutation Res,103:119-126.

36. Nakamura $H$ and Yamamato $T$ (1983): The active part of the $\{6\}$ - gingerol molecule in mutagenesis.Mutation Res, 122: 87-94.

37. Paulsson B, Grawe $\mathbf{J}$ and Tornquist $\mathbf{M}$ (2002): Hemoglobin adducts and micronucleus frequencies in mouse and rat after acrylamide or $\mathrm{N}$-methylolacrylamide treatment.Mutant. Res. 516(1-2):101-111.
38. Phillips S, Hutchinson $\mathbf{S}$ and Ruggier $\mathbf{R}$ (1993): Zingiber officinale does not affect gastric emptying rate.Anathesia ., 48 : 39395.

39. Qian D S and Liu Z S (1992): Pharmacologic studies of antimotion sickness actions of ginger.Chung Kuo Chung His Chieh Ho Tsa Chih ., 12: 95-98.

40. Sakr S A (1993): Surface ultrastructure of intestinal mucosa of Tilapia nilotica exposed to diazinon.J.Egypt.Ger. Soc.Zool., 12 (C):135-152.

41. Sharma S S and Gupta Y K (1998): Reversal of cisplatin-induced delay in gastric emptying in rats by ginger. $\mathrm{J}$. Ethnopharmacol., 62: 49-55.

42. Shulick P (1996): Ginger common spice and wonder drug. Vermont: Herbal free press, Ltd.

43. Smith E A and Oehme F W (1991). Acrylamide and polyacrylamide :a review of production, uses, environmental fate and neurotoxicity. Rev.Environ.Hlth., 9 (14): 215-228.

44. Specian $R$ and Neutra $M$ (1980): Mechanism of rapid mucous secretion in goblet cells stimulated by acetylcholine. J.Cell Biol., 85: 626-640.

45. Stewart J J, Wood M J, Wood CD and Mims ME (1991): Effects of ginger on motion sickness susceptibility and gastric function. Pharmacology, 42: 111-120.

46. Tareke E, Rydberg P, Karlson P, Ericksson $S$ and Tornquist $M$ (2002). Analysis of acrylamide, a carcinogen formed in heated foodstuffs.J.Agric. Food. Chem., 50 (17): 4998-5006.

47. Williams JM (1994): Jude's herbal home remedies.Minn:Llewellyn Publications .

48. Winton D J and Flaks B (1988): Effect of fasting on aggregation of hepatocyte rough endoplasmic reticulum in adrenalctomized and 3 ME DAB- treated rats. Quantitative electron microscope Study .Br.J.Exp. Pathol., 69: 877-889.

49. World Health Organization (WHO) (2002): Additional research on Acrylamide in food essential.Scientists declare.Geneva, June 2002, Summary Report.

50. Yamahara J, Huang Q, Li L, Xu L and Fujimura H (1990). Gastrointestinal motility enhancing effect of ginger and its active constituents.Chem.Pharm.Bull., 38: 430-431.

51. Zhongguo zhong XI YI Jie He Za Zhi (1992): Pharmacological studieof antimotion sickness actions of ginger. Lie $\mathrm{Kx}$, Ww wk, He E, Sunhl. Feb; 12 (2): 95-8,70. 
دراسات هستولوجيه و تركيبيه دقيقه للتأثير المحتمل لمستخلص الزنجبيل

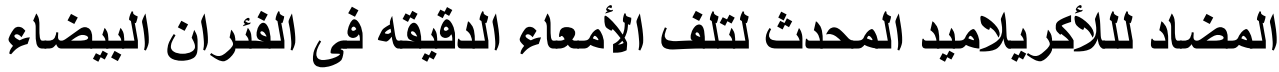

\section{هاله جلال محمد الطنطاوى}

قسم علم الحيوان - كلية العلوم- جامعة عين شمس شلطم

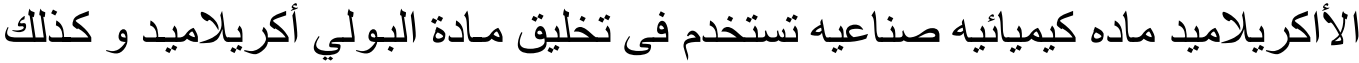

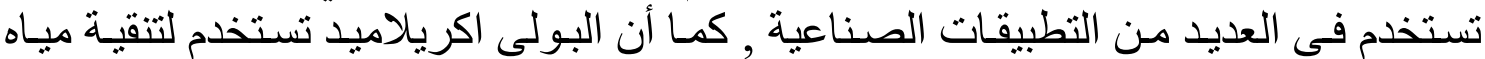

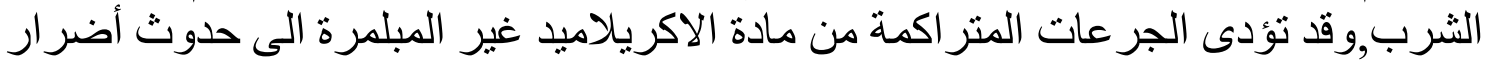

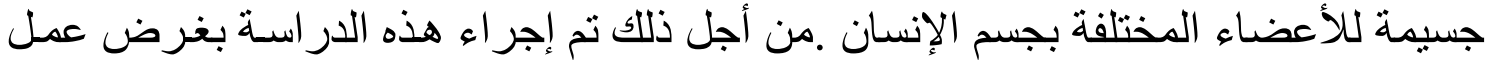

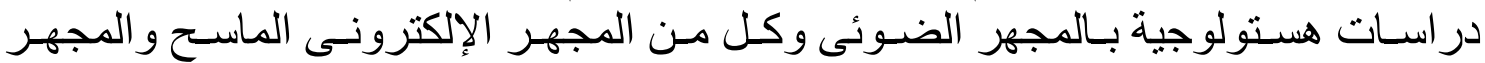

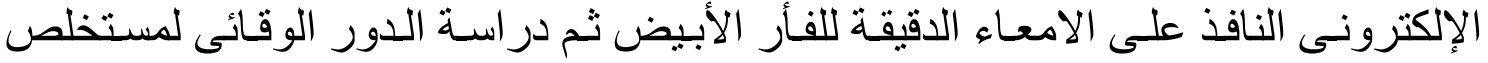

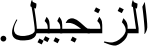

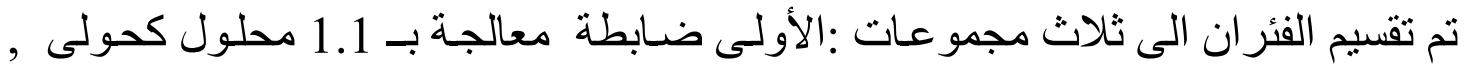

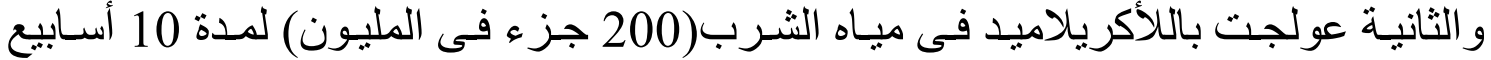

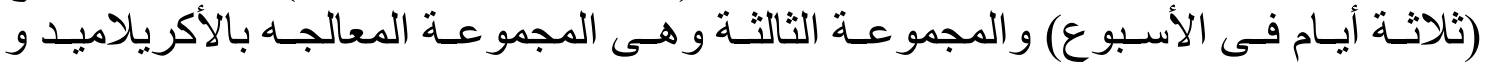

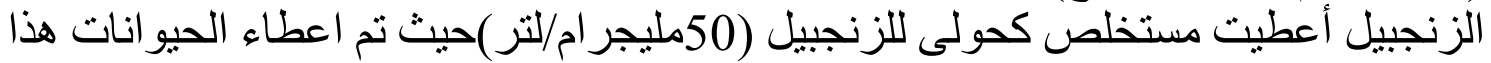

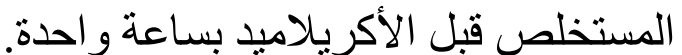

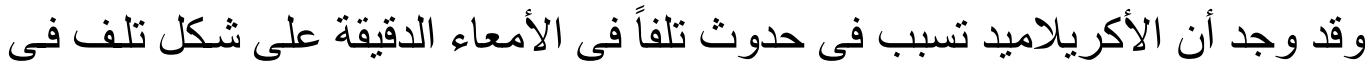

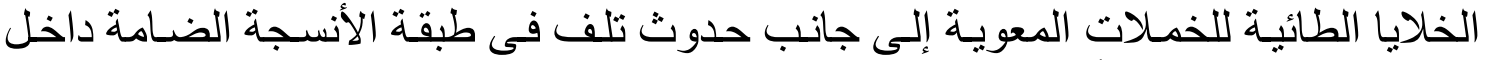

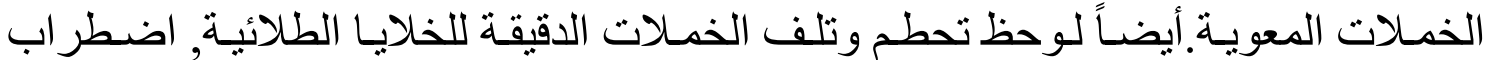

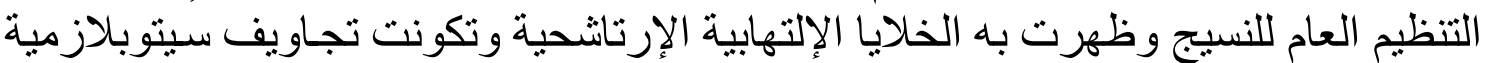

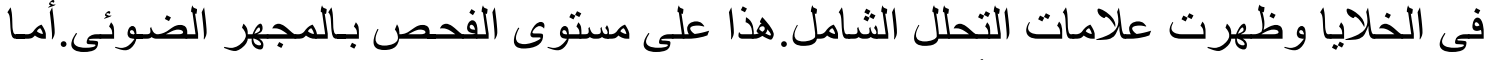

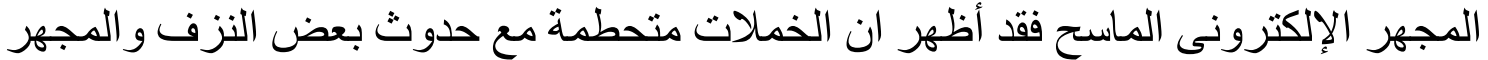

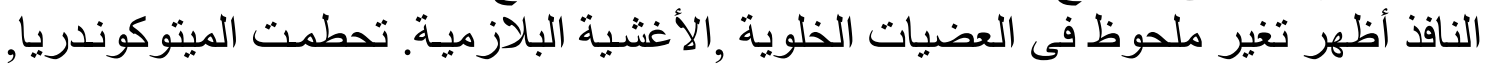

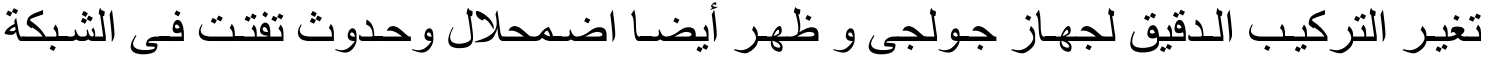

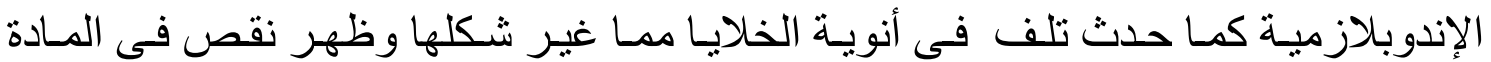

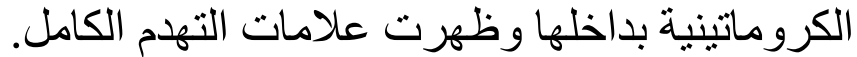

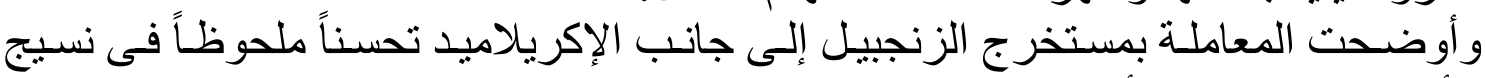

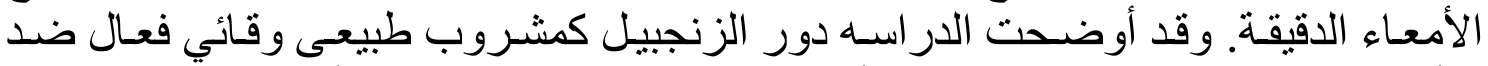
التأثير الضار لهذه المادة و التى يمكن أن تنتج من طريقة طبخ بعض الزئن الأطعة النشوية. 